\title{
WATER VAPOUR ADSORPTION ON DNA
}

\author{
D. Balköse*, B. Alp and S. Ülkü \\ İzmir Institute of Technology, Chemical Engineering Department, Gülbahçeköyü, 35430, Urla, İzmir
}

DNA adsorbed very low amount of water at low relative humidities, amount of adsorption increased to $140 \%$ at $98 \%$ relative humidity at $25^{\circ} \mathrm{C}$. Heat of adsorption was $109 \mathrm{~kJ} \mathrm{~mol}^{-1} \mathrm{H}_{2} \mathrm{O}$ for the increase of moisture content from 0 to $1.96 \%$. At higher moisture contents the heat released approached heat of condensation of water vapour on free liquid surface, $40 \mathrm{~kJ} \mathrm{~mol}^{-1} \mathrm{H}_{2} \mathrm{O}$.

Keywords: DNA, gravimetric adsorption, heat of adsorption, microcalorimeter, water vapour

\section{Introduction}

DNA is a molecule which is present in the nucleus of each living cell. It is the molecule which synthesizes proteins. DNA conformation [1], electrical conductivity [2] and density [3] depend on the amount of water it contains. The phosphate groups, nitrogen and oxygen atoms of the base pairs in DNA bind to water molecules by hydrogen bonding. DNA adsorbs moisture from atmosphere and it is a water soluble macromolecule. The state of water in DNA has been investigated by X-ray diffraction, by inelastic neutron scattering [4] and melting of frozen water in DNA [5] by previous workers. The bound water in frozen DNA does not show ice melting endotherm. This is due to distribution of electric charges around phosphate groups. Dielectric study on hydration of DNA in water-ethanol solutions showed that 19 and 13 molecules of water per nucleotide are required for B-DNA and A-DNA respectively to keep the double helix. Studies of water vapour adsorption of DNA films by IR spectroscopy have shown that the hydrogen bonded water peak maxima shifted from 3473 to $3583 \mathrm{~cm}^{-1}$ as moisture content increases. This was attributed to the formation of a thin liquid water film on the surface of DNA [6].

The interaction between DNA and water were described by quantum mechanical methods [2] and by molecular dynamics [7]. Water network around simulated duplexes was more conformation specific rather than sequence specific [7]. Water influences DNA stability and the contribution of water molecules to the energy of DNA helical structure was found from the energy spectrum of the bound water and enthalpy of helix-coil transformation [8]. Energy change was inversely proportional to amount of bound water per nucleotide.
In studying DNA by IR spectroscopy diffuse reflectance [4], attenuated total reflectance [9], transmission from film [8] and $\mathrm{KBr}$ disc [10] techniques were used in previous studies. Moisture content of the samples were changed either by water vapour adsorption from air and adding liquid water [4], or equilibration in vapour phase of saturated salt solutions [8]. The state of the sample could change during sample preparation, handling and measurement stages using these techniques.

This research aims studying water vapour adsorption of DNA in situ. Outgassing the samples in vacuum and sending water vapour at controlled rate and pressure prevented any change in state of the sample between outgassing and measuring stages. No change in state of the sample occurs since the sample was not transferred from preparation environment to measuring environment. While water vapour was sent continuously at a low rate in gravimetric system, water vapour at different pressures was sent in steps in FTIR Drift cell and microcalorimeter cell.

\section{Experimental}

In the present study sodium salt DNA obtained from calf tymus (Sigma) was used.

The morphology of the fibres was investigated by scanning electron microscopy using Philips VL30 SFEG SEM.

Equilibrium and kinetics of water vapour adsorption on calf thymus DNA was studied by Cahn gravimetric adsorption system described in a previous paper [11]. The system has Edwards ultra high vacuum system and all vacuum glass valves were from Scientific Glass Company. Adsorption isotherm of water vapour on DNA at $25^{\circ} \mathrm{C}$ was determined after

* Author for correspondence: devrimbalkose@iyte.edu.tr 
outgassing the sample at $0.1 \mathrm{~Pa}$ at $50^{\circ} \mathrm{C}$ for $24 \mathrm{~h}$ and cooling down to $25^{\circ} \mathrm{C}$. System was evacuated to $0.1 \mathrm{~Pa}$ pressure. $50^{\circ} \mathrm{C}$ outgassing temperature was chosen to be lower than the denaturation temperature of calf thymus at low moisture contents [12]. Saturated water vapour having $3.1 \cdot 10^{3} \mathrm{~Pa}$ pressure at $25^{\circ} \mathrm{C}$ was sent to $3 \mathrm{dm}^{3}$ adsorption chamber initially under $0.1 \mathrm{~Pa}$ pressure at a very slow rate $\left(1.1 \cdot 10^{-3} \mathrm{~cm}^{3} \mathrm{~s}^{-1}\right)$ to keep the sample in equilibrium with water vapour. Thus the vapour pressure in the adsorption chamber increased continuously till the pressure of the chamber was $3.1 \cdot 10^{3} \mathrm{~Pa}$. The pressure of the chamber and the mass of the sample were recorded to obtain adsorption isotherm data. The process was repeated three times for the same sample.

For kinetic measurements step changes in water vapour pressure from 0.1 to $3.1 \cdot 10^{3} \mathrm{~Pa}$ and from $3.1 \cdot 10^{3}$ to $0.1 \mathrm{~Pa}$ was carried out. The process was repeated three times after drying at $50^{\circ} \mathrm{C}$ at $0.1 \mathrm{~Pa}$ and cooling to $25^{\circ} \mathrm{C}$. Setaram C-80 microcalorimeter was used for adsorption heat determination. The set up shown in Fig. 1 was used for drying the sample under vacuum and sending water vapour in steps on the sample and measuring the released heat at $25^{\circ} \mathrm{C}$ by Setaram C-80. Power vs. time was recorded during experiments and from the peak areas heat of adsorption was determined for each step increase in relative humidity. The process was repeated twice for the same sample.

Digilab Excalubur FTIR spectrophotometer was used for recording the FTIR spectra. Water adsorption was also studied by in situ DRIFT FTIR by sending water vapour at 11,19 and $38 \%$ relative pressure at $25^{\circ} \mathrm{C}$ on DNA dried at $50^{\circ} \mathrm{C}$ under $0.1 \mathrm{~Pa}$ vacuum then cooled down to $25^{\circ} \mathrm{C}$. Harricks high pressure cell, Leybold ultra high vacuum system with turbomolecular pump were used in the system. Water vapour difference spectrum was obtained by subtracting dried DNA spectrum from spectra of water vapour adsorbed DNA.

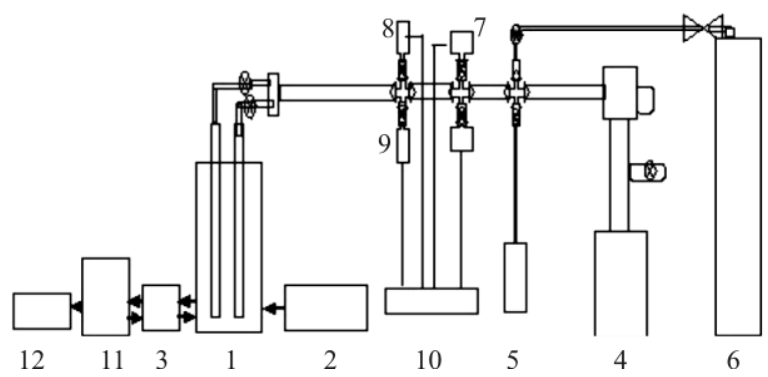

Fig. 1 Microcalorimeter adsorption system 1 - microcalorimeter (Setaram C-80), 2 - power module, 3 - control panel (CS 32), 4 - turbo pump, 5 - water reservoir, 6 - gas bottle, 7-1-100 Pa pressure gauge (MKS Baratron gauge), $8-0-10^{5} \mathrm{~Pa}$ pressure gauge (thermocouple gauge), $9-10-0.1 \mathrm{~Pa}$ pressure gauge (inverted magnetron), 10 - pressure reader, 11 - computer, 12 - printer

\section{Results and discussion}

\section{Morphology of DNA}

The micrographs in Fig. 2 show DNA was in fibrous form. Molecules with double helix structure form super helix. The material consists of $0.1-0.5 \mu \mathrm{m}$ diameter fibres.
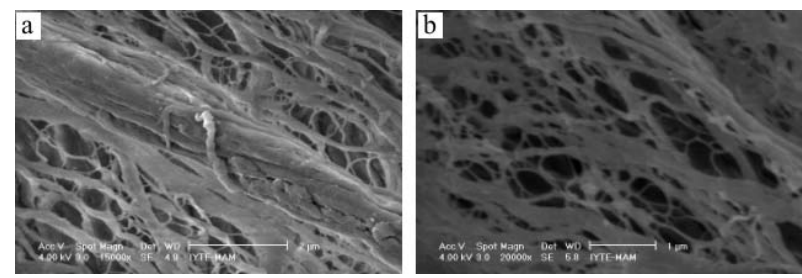

Fig. 2 SEM micrographs of DNA at a $-N=15000 \times$, $\mathrm{b}-N=20000 \times$

\section{Adsorption equilibrium}

It was observed that DNA adsorbed 4-5\% water up to $40 \%$ relative humidity, amount of adsorption increased to $140 \%$ at $98 \%$ relative humidity as seen in Fig. 3. Adsorption was reversible as reported by Tsereteli et al. [12], nearly the same adsorption isotherm was obtained in three successive runs. The water vapour effected reversibly DNA molecules. The isotherm fitted to Chung-Pfost model in Eq. (1) with $\mathrm{A}$ and $\mathrm{B}$ being equal to 1.01 and 0.0486 , respectively. The regression coefficient was 0.89 .

$$
\ln \left(-\ln \left(a_{\mathrm{w}}\right)\right)=\ln A-B(m)
$$

where $a_{\mathrm{w}}$ is water activity or relative pressure and $B$ is water mass fraction in DNA.

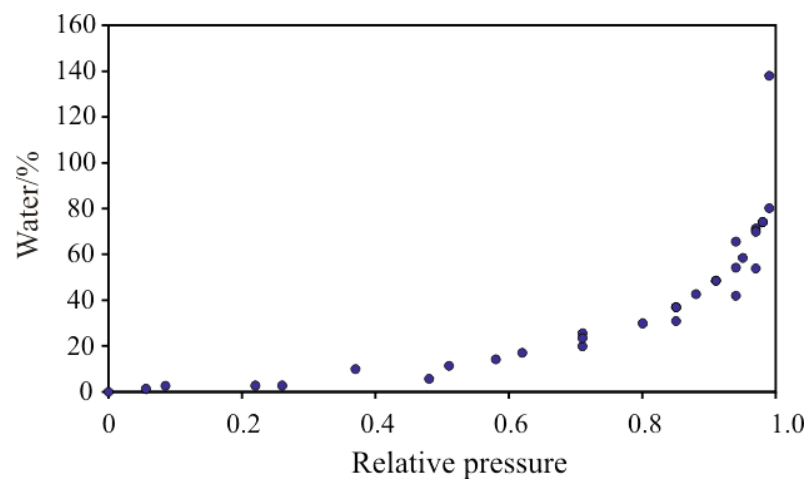

Fig. 3 Adsorption isotherm of water vapour on DNA at $25^{\circ} \mathrm{C}$

\section{Adsorption and desorption kinetics}

Adsorption rate increases with time indicating diffusion and relaxation of polymer chains occur simultaneously with adsorbed moisture as seen in Fig. 4. Thermodynamically it is expected that B-DNA double helix with pitch distance $3.4 \mathrm{~nm}$ transform to 
A-DNA with smaller pitch distance $2.82 \mathrm{~nm}$ on loosing bound water [1]. According to findings in the present study this transformation is not instantaneous, it takes time. Adsorption was slower than desorption indicating the swollen polymer does not have time to relax into the dried form for the fast desorption period. After complete drying of DNA, the molecules take their A form and the same adsorption rate curve is observed in the second run.

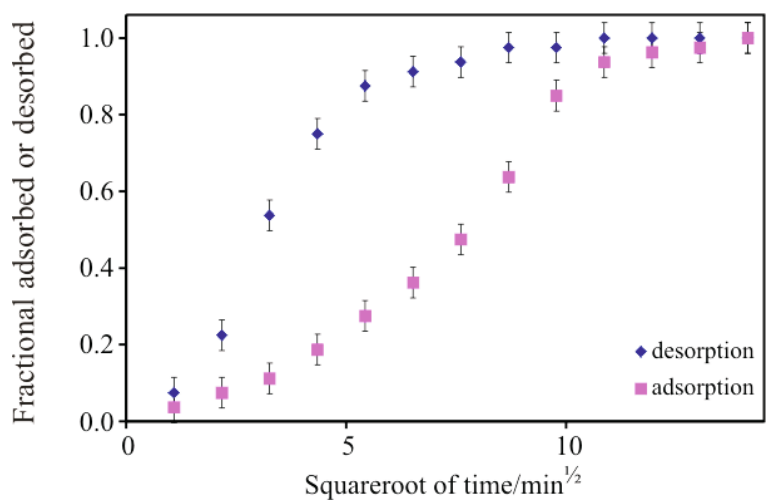

Fig. 4 Change of fraction of adsorbed or desorbed water from DNA with time

From the initial slopes of fraction adsorbed or desorbed vs. square root of time curves in Fig. 4 Fickian diffusion coefficients $\left(D, \mathrm{~m}^{2} \mathrm{~s}^{-1}\right)$ were found by using Eq. (2) for infinite cylindrical fibres

$$
M_{\mathrm{t}} / M_{\infty}=4 / r(D t / \pi)^{1 / 2}
$$

where $M_{\mathrm{t}}$ amount adsorbed or desorbed at time $t, M_{\infty}$ is amount adsorbed or desorbed at equilibrium. The average fibre diameter is taken as $0.3 \mu \mathrm{m}$ in predicting the diffusion coefficients. Diffusion coefficients were found as $3.46 \cdot 10^{-17}$ and $5.04 \cdot 10^{-16} \mathrm{~m}^{2} \mathrm{~s}^{-1}$ for adsorption and desorption. The higher value of the diffusion coefficient for desorption than that of desorption also confirms the change of conformation of the molecules with moisture adsorption.

\section{Heat of adsorption}

Adsorption of water vapour on DNA was an exothermic process and the heat released on adsorption depends on initial moisture content of DNA. From the areas of peak maxima in Fig. 5 heat of adsorption were determined and reported in Table 1. The heat of adsorption was very high when DNA was dry. $109 \mathrm{~kJ} \mathrm{~mol}^{-1} \mathrm{H}_{2} \mathrm{O}$ energy were released when the moisture content increases to $1.96 \%$. When the moisture content increases from 1.96 to $3.34 \%$ a lower amount of heat $80 \mathrm{~kJ} \mathrm{~mol}^{-1} \mathrm{H}_{2} \mathrm{O}$ was released. At higher moisture contents the heat released approached heat of condensation of water vapour on free liquid surface, $40 \mathrm{~kJ} \mathrm{~mol}^{-1} \mathrm{H}_{2} \mathrm{O}$.

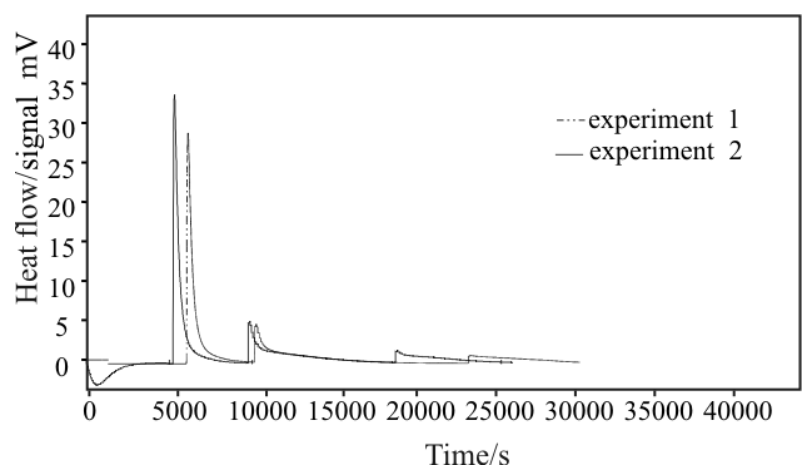

Fig. 5 Energy flow $v s$. time for water vapour adsorption. The peaks belong to sending water vapour at relative humidities shown in Table 1

Table 1 Change of heat of adsorption at $25^{\circ} \mathrm{C}$ with relative humidity and moisture content of DNA

\begin{tabular}{cccc}
\hline $\begin{array}{c}\text { Experiment } \\
\text { No. }\end{array}$ & $\begin{array}{c}\text { Relative } \\
\text { humidity/\% }\end{array}$ & $\begin{array}{c}\text { Solid } \\
\text { moisture/\% }\end{array}$ & $\begin{array}{c}\Delta H / \\
\mathrm{kJ} \mathrm{mol}^{-1} \mathrm{H}_{2} \mathrm{O}\end{array}$ \\
\hline 1 & 29 & 1.96 & 609 \\
1 & 36 & 3.34 & 84 \\
1 & 44 & 4.28 & 40 \\
2 & 29 & 2.61 & 92 \\
2 & 38 & 4.33 & 73 \\
2 & 53 & 4.69 & 62 \\
\hline
\end{tabular}

\section{FTIR study}

FTIR spectra of DNA before and after drying at $50^{\circ} \mathrm{C}$ under $0.1 \mathrm{~Pa}$ vacuum in Fig. 6 showed common vibrational peaks for hydrogen bonded $\mathrm{OH}$ stretching being maximum at $3400 \mathrm{~cm}^{-1}, \mathrm{~N}-\mathrm{H}$ stretching at $3200 \mathrm{~cm}^{-1}$ as a shoulder, C-H stretching $2900 \mathrm{~cm}^{-1}$, bending vibration of water at $1600 \mathrm{~cm}^{-1}$, and symmetric stretching of $\mathrm{PO}_{2}$ groups at $1225 \mathrm{~cm}^{-1}$. DNA in dry form also contained water and in outgassing procedure it was not possible to remove water. Intensity of the bands at 3400 and $1600 \mathrm{~cm}^{-1}$ and in the region $1000-500 \mathrm{~cm}^{-1}$ decreased on drying of DNA, indicating all these bonds are related to water molecule vibrations. Difference spectra of DNA in dry form and in equilibrium with 11,19 and $38 \%$ relative humidities were obtained and shown in Fig. 7. Observation of two peaks at 3640 and $3605 \mathrm{~cm}^{-1}$ indicated there were two types of binding sites of water on DNA. The breadth of $\mathrm{OH}$ stretching peak is smaller than found by previous workers under similar conditions [4]. $\mathrm{N}-\mathrm{H}$ vibrations were increased with water vapour adsorption but did not change with amount of adsorption. No peak appears for the bending vibrations of $\mathrm{H}_{2} \mathrm{O}$ molecules in the difference spectrum at 1600 but a peak at $2200 \mathrm{~cm}^{-1}$ increasing in intensity with amount of moisture adsorbed was observed. 


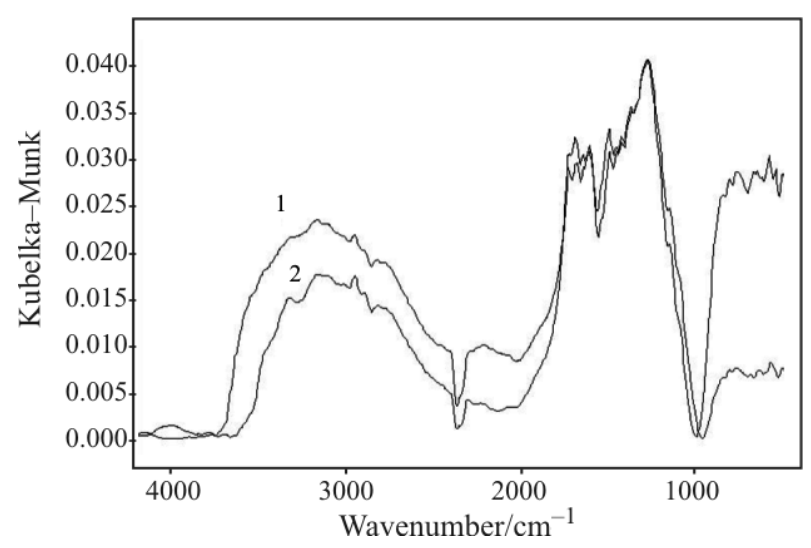

Fig. 6 Drift FTIR spectra of 1 - water vapour adsorbed and 2 - dry DNA

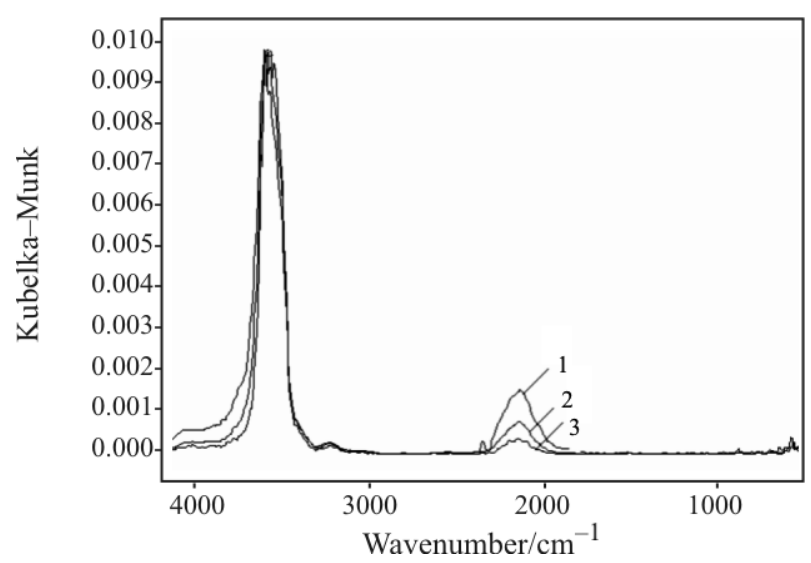

Fig. 7 Difference spectra of water vapour adsorbed DNA (in equilibrium with $1-38,2-19$ and $3-11 \%$ relative humidity air at $25^{\circ} \mathrm{C}$ ) and dried DNA

\section{Conclusions}

The phosphate groups, nitrogen and oxygen atoms of the base pairs in DNA bind to water molecules by hydrogen bonding. It was observed that DNA adsorbed very low amount of water at low relative humidities, amount of adsorption increased to $140 \%$ at $98 \%$ rela- tive humidity at $25^{\circ} \mathrm{C}$. The higher value of the diffusion coefficient for desorption than that for adsorption also confirms the change of conformation of the molecules to the ones with more free space with moisture adsorption. The heat of adsorption was very high when DNA was dry and it decreases to heat of condensation of water vapour to free water surface as the moisture content increases.

Observation of two peaks at 3640 and $3605 \mathrm{~cm}^{-1}$ indicated there were two types of binding sites of water on DNA. It was clearly understood that water molecules in DNA were hydrogen bonded from FTIR spectra.

\section{References}

1 I. M. Parror, V. Laux, V. Urban, M. Haertlein and V. Trevor Forsyth, Physics B., 385-390 (2006) 845.

2 L. M. Weterhoff and K. Merz, J. Macromol. Graph. Mod., 24 (2007) 440.

3 T. V. Chalikian, J. Völker, A. R. Srinavasan, W. K. Olsen and K. J. Breslauer, Biopolymers, 50 (1999) 459.

4 L. Michhalarian, I. A. Beta, J. C. Li, S. Ruffle and R. Ford, J. Macromol. Liq., 101 (2002) 19.

5 G. M. Mrevlishvili, A. P. S. M. C. Carvalho, M. A. V. Ribeiro da Silva and T. P. Mazinarasvili, J. Therm. Anal. Cal., 65 (2001) 133.

6 T. Umehara, S. Kuwabara, S. Mashimo and S. Yagihara, Biopolymers, 30 (2004) 649.

7 C. Balasubramanian, R. P. Ojha and S. Maiti, Biochem. Biophys. Res. Commun., 355 (2007) 1081.

8 M. Seminov, T. Bolbukh and V. Maleev, J. Mol. Struct., 408/409 (1997) 213.

9 A. V. Stepantugin, S. P. Samijlenka, O. I. Martynenko and D. M. Hovarun, Spectrochim. Acta, Part A 67 (2005) 2267.

10 B. R. Parker and G. P. Khare, J. Mol. Spectrosc., 41 (1972) 196.

11 S. Ülkü, D Balköse, T Çağa, F. Özkan and S. Ulutan, Adsorption, 4 (1999) 63.

12 G. I. Tsereteli, T. V. Belopolskaya and N. A. Grunina, J. Therm. Anal. Cal., 92 (2008) 711.

DOI: $10.1007 / \mathrm{s} 10973-008-9356-9$ 